\title{
Self-Representation of Court and City in Flanders and Brabant in the Fifteenth and Early Sixteenth Centuries
}

\author{
WIM BLOCKMANS \& ESTHER DONCKERS*
}

M edieval society was characterized by a high degree of social inequality. This situation requred a continuous justification so that the lower classes could be persuaded to accept their less attractive lot in good part. It is well known that the Church's social doctrine urged the faithful to submit to a social order that was presented as being ordained by God. ${ }^{1}$ Besides religious arguments, rulers and those in authority likewise adopted symbolic means to show their position of power in a positive light to their subjects, and to involve them in it through certain rituals. In 1976 Jacques Le Goff broke new ground with his interpretation of the symbolism of vassalship, as Percy Schramm had done earlier with that of monarchy. ${ }^{2}$ Both of these model studies have inspired us to a more global analysis of political symbolism in the mass displays that princes and city governments, often in consultation, organized in the towns of the fifteenth-century Low Countries.

\footnotetext{
"The section concerning the Bruges entry of 1515 is based on research by Esther Donckers She acknowledges the text of this chapter as written by Wim Blockmans

'A Black, 'The Individual and Society', in. J H Burns (ed ), Medieval Politıcal Thought (Cambridge 1988) 588-604

2 J Le Goff, 'Le rituel symbohque de la vassalıté', in Pour un autre moyen âge (Paiss 1977) 349-420, P E Schramm, Herrschaftszetchen und Staatssymbollk, 3 vols (Stuttgatt 1956), Chr de Mérindol, 'L'imagınaıte du pouvorr à la fin du Moyen Age Les prétentıons royales', in. J Blanchard (ed), Représentation, pouvour et royauté à la fin du moyen âge (Pat1s 1995) 65-92
} 
In this contribution we shall focus on those public occasions at which princes and their retinues appeared in the city. By the very nature of events, these were practically always processions and ritual proceedings, often a combination of both. Two aspects seem to be important here: first, we shall examine how the processions were structured, and thus possibly fulfilled a symbolic function for the diverse categories of participants; then we shall look at how political messages and activities were presented to the public by means of symbols. In this way we hope to add another dimension to the fairly recent interest in the public media during the Middle Ages, and also, of course, to the study of political processes using non-fictional sources. ${ }^{3}$

From the fourteenth to the sixteenth centuries rulers gave increasingly more attention to demonstrating their status and ideals to the general public. ${ }^{4}$ The growing use of the procession as the means of mass communication par excellence is in itself an interesting phenomenon. Where did such a need come from? Were the subjects becoming more emancipated, or did the rulers, with their levels of ambition growing, feel the need to include the people in political events more than ever before? Certainly, in that period the states strengthened their grip on society considerably, a fact that could be seen in the sharply rising tax burden, amongst other things. This led to unrest, more than ever before, and rulers and local governments were obliged to take expensive, repressive measures. It was in every respect more efficient, and considerably cheaper, to use symbolic measures to involve the populace emotionally in the state than to force them with an iron hand. The increasing use of symbolic mass communication can thus be interpreted as a well-chosen way of strengthening authority. ${ }^{5}$ It may well be that this interpretation is only legitimate with hindsight, and that contemporaries could not fully weigh up the effects of their actions, or were not even conscious of them. If that were so, then the question arises of what drove the organizers to produce more and more sophisticated and magnificent spectacles. ${ }^{6}$ The motivation inherent in the medium, and the dynamics

\footnotetext{
${ }^{3}$ W Faulstıch, Medien und Offentlichkeiten ım Mittelalter 800-1400 (Gottıngen 1996)

'A Boureau, 'Ritualité politıque et modernité monarchıque', in. N Bulst, R Descimon \& A Guerreau (eds ), L'Etat ou le Rot. Les fondatıons de la moderntté en France (XIVeXVIIe stècle) (Parıs 1996) 9-25

${ }^{5}$ W Blockmans, A Htstory of Power in Europe Peoples, Markets and States (Antwerp/ New York 1997) 267-301

${ }^{6} \mathrm{H}$ Soly, 'Plechtige intochten in de steden van de Zuıdelıjke Nederlanden tıjdens de overgang van middeleeuwen naar nieuwe tijd communicatıe, propaganda, spektakel', Tydschrift voor Geschtedents 97 (1984) 341-61, J Chráscickı, 'Ceremon1al Space', in A Ellenus (ed ), Iconography, Propaganda, and Legtimation (Oxtord 1998) 193-216
} 
attached to it, will have to be balanced against that of the political context In any event, the question under discussion remains what function could symbolism, with all its political propaganda and the apparent participation of the people, have in the real political processes? The Fathers of the Church had derived worldly power from the heavenly order, in their tradition, legitimation of actual asymetric social relations had to be based on metaphysical concepts

\section{Models}

In expanding increasingly impressive public spectacles rulers made eager use of models which had been developed in other contexts Public rituals developed in at least four institutional areas during the Middle Ages Here we are deliberately ignoring rural communities undoubtedly a rich ritual symbolism grew up there too, but it is unlikely that it penetrated through to the princely and urban curcles now under consideration In the first place because it was the oldest - came the Church The adventus, the ceremonial first entry of a bishop into his see, fitted into the late Roman tradition of the triumphal procession This ceremonial welcome by both the civic community and the cathedral chapter was coupled with a tour of the city and the changing of vestments, symbolizing the investiture first of temporal and then of spiritual power In addition to this the Church expanded the procession, $1 \mathrm{e}$ the showing of relics, on a public holiday or on the feast-day of the saint concerned During the thirteenth century the worship of the body of Christ spread with general processions on Corpus Christı the Eucharıst was carried under a canopy The French kings adopted this model in the fourteenth century by showing themselves to the people in procession, under a canopy, as Christ's representatıve on earth This association made a forceful contribution to the sacralization of the monarchy ${ }^{7}$ King Richard II used the Ecce Agnus Dev emblem for his entry into London in 1392 Henry V borrowed both from the biblical tradition and from the ancient triumph $\mathrm{He}$ wore a purpur mantle entering the 1ecently conquered cities of Harfleur and Rouen in 1415 and referred to his victory at Agincourt as a trumph when he entered into London later that

\footnotetext{
${ }^{7}$ B Guenee \& F Lehoux, Les entrees royales françalses de 1328 a 1515 (Parıs 1968) 13 20, M Rubin, Corpus Christ The Eucharist in Late Medieval Culture (Cambridge 1991) 25860 , A Guery, 'Le rol et Dieu, le rol est Dieu', in Bulst, Descimon \& Guerredu, L Etat ou le Ror, 2747
} 
year. At the same occasion, however, the motto of Psalm 117, 'Benedictus qui venit in nomine Domini', referred to Christ's entry into Jerusalem on Palm Sunday. ${ }^{8}$

Processions were exceptionally flexible rituals which could equally well be held for a local or a general church purpose, on fixed days and, by special proclamation, in connection with a particular emergency, or as thanksgiving. In this respect, too, church ritual was widely used for political ends such as praying for, or celebrating, military successes. Considering the Church's central position in the organization and purpose of public life, it was logical that church rituals also lent their forms to ceremonies that were not purely religious. In certain cases, church liturgy, such as that of baptism, marriage and funeral, switched over smoothly to a dynastic ceremony. The hierarchic structure of processions, where the holiest object appeared at the end or right in the middle, became the basic pattern for all medieval processions. ${ }^{\text {" }}$

The knighthood, as a second basic institution of European history, developed its own form-language which was very much in evidence in late medieval ceremonies. In the first place, of course, it was concerned with the stylization of the mounted knight in armour, with his heraldic symbols and personal devices. It was usual for princes and therr retinue to appear in public in this sort of finery. Thanks to their horses, whose colour and breed also conveyed hierarchy, knights were elevated above the ordinary people and enhanced their fighting power. The sign language of their banners, pennants and coats of arms was imitated by civic communities. During the fourteenth century their battles, stylized as a game in the form of tournaments, were absorbed into the cultural expression of the urban upper class. ${ }^{10}$ The idealization of chivalric life and courtly love in romances permeated the cultural baggage shared by wider circles, and produced themes and forms for various representations in the urban environment.

\footnotetext{
${ }^{8}$ Sarah Tolme, 'Quia hic homo multa sıgna facit Henry V's Royal Entry into London, November 23, 1415', in M. Gosman, A J Vanderjagt \& J Veenstra (eds), The Propagation of Power in the Medieval West (Groningen 1997) 363-79, esp 366-8

"Compare M James, 'Ritual Drama and Social Body in the Late Medieval English Towns', Past and Present 98 (1983) 3-29, H Roodenburg, "Splendeur et magnificence" Processions et autres célébrations à Amsterdam au XVIe siècle', Revue du Nord 69 (1987) 515-33

${ }^{10} \mathrm{D}$ Nicholas, 'In the Pit of the Burgundian Theatre State Urban Traditions and Pincely Ambitions in Ghent, 1360-1420', in B A Hanawalt \& K L Reyerson (eds), City and Spectacle in Medieval Europe (Minneapolis/London 1991) 137-52
} 
Banquets belonged to the feast culture of courts and commons. ${ }^{11}$

The court was the third institutional frame that gave form to late medieval public rituals. Princes belonged heart and soul to the world of chivalry, a world in which they were 'the best'. For the sake of their position at the top of the hierarchy they stressed, apart from the royal coronation rites, two specific rituals: that of homage and that of entry. Both rites stemmed from other practices, feudal homage and episcopal jocundus adventus respectively. Rulers applied them in the field of statutory law, with personal vassalage and sacralization as additional dimensions. ${ }^{12}$ The so-called Blijde Intrede (Joyous Entry) became the solemn moment when a ruler made his first visit to one of his territories or cities and swore to respect their rights, privileges and customs, receiving in exchange the homage and oath of fealty of his subjects. This mutual promise of protection on one hand and fidelity and support on the other derives from feudal oaths, as far as the form is concerned. By virtue of the reciprocal pattern the bonds could also be broken when either one of the parties concerned failed to fulfil the conditions. That, too, was made clear by the use of ritual. $^{13}$

The court was a perfect example of a hierarchic environment where, at any moment, in every act, the order of rank was formalized and symbolized. The rituals of eating and of the household formed the basis for the arrangement of a large part of court offices. The names given to functions at the Burgundian court reflected not only the great sectors of material welfare (bread, meat, wine, chamber, treasury, stables) but also the hierarchy of knighthood. ${ }^{14}$ The superiority of the chivalric order is seen in the fact that the highest civil court officials, the chancellors, were, without exception, elevated to the knighthood immediately upon appointment. ${ }^{15}$

${ }^{11} \mathrm{H}$ Ple1j, Dromen van Cocagne. Middeleeuwse fantasleen over het volmaakte leven (Amsterdam 1997) 250-5, comments as an example, on the Dutch version of the Roman de la Rose by Jan van Boendale in the furst half of the fourteenth century

${ }^{12} \mathrm{~J}$ M Nieto Sona, Ceremonias de la realeza Propaganda y legittmación en la Castilla Trastámara (Madrid 1993)

${ }^{13}$ A Holenstein, Die Huldigung der Untertanen Rechtskultur und Herrschaftsordnung (800-1800) (Stuttgart 1991)

${ }^{14}$ W. Paravicin, 'The Court of the Dukes of Burgundy A Model for Europe?', in R.G. Asch \& A.M Birk (eds.), Princes, Patronage and the Nobtlity The Court at the Beginning of the Modern Age, c 1450-1650 (Oxford 1991) 69-102

${ }^{15} \mathrm{P}$ Cockshaw, Le personnel de la chcncellerie de Bourgogne-Flandre sous les ducs de Bourgogne de la maison de Valous (1384-1477) (Kortrık/Heule 1982) 44-52 
When the court moved outside its own residence, in a city for example, it stressed its individual character and internal hierarchy through ranking order, heraldry and other insignia.

The town was the fourth institution to create its own public rituals. The dividing line with the Church and even with the world of chivalry was never complete, as can be seen from the urban tournaments. Each town celebrated its own patron saint, too, whose procession touched the whole community. Some processions attracted visitors from far and wide because particular value was attached to the power of the relics or the global spectacle: for example, the procession of the Sacred Blood in Bruges, the Sacrament procession in Oudenaarde, the Easter and Christmas processions in Mechelen, the procession of Our Lady in Louvain, and in Lier the St. Gummarus procession. During the fifteenth and sixteenth centuries these parades included new floats, giants, amusements, games and theatrical performances, all of which increased their appeal. These were originally Church processions which grew into manifestations of a typically urban identity. At the same time the guilds and brotherhoods also organized processions for their own services. Shrove Tuesday celebrations flourished with large-scale spectacles, especially in the urban context. During the first decennia of the fifteenth century the Ghent city council spent large sums of money on improving the festivities and, at the same time, keeping them under control. Thus they provided payment for a jingling Johnny, the koning van de ribauden ('king of ribaldry') and his twenty lads, and for officials patrolling with bodyguards in armour, and also for trumpeters, pipers, minstrels, bards, poets and players, enormous quantities of wax, and more than 12,000 torches to illuminate the city. ${ }^{16}$ The town version of the tournament was the archery contest, in which groups from other towns also took part; a little later chambers of rhetoric would organize similar competitions. ${ }^{17}$ In the purely political field, the urban communities established ceremonies for the annual appointment of the town council, and the guilds, too, developed their own festival culture.

\section{Functions}

All these costly ceremonies did more than merely fulfil the desire for aesthetic or other display. We shall distinguish here between four political

\footnotetext{
${ }^{16}$ Nicholas, 'In the Pit'.

${ }^{17}$ B.A.M. Ramakers, Spelen en figuren. Toneelkunst en processiecultuur in Oudenaarde tussen Middeleeuwen cn Moderne Tijd (Amsterdam 1996).
} 
functions: 1. the celebration of a formal act with public significance; 2 . proclamation of this to the people; 3. affirmation of mutual support; and 4. competition between communities symbolically expressed. In all the traditions mentioned the formal act can be distinguished from the public proclamation and the celebration thereof.

\section{THE FORMAL ACT}

Church rituals were concerned on one hand with the sacraments (Mass, extreme unction, baptism, marriage), and on the other with carrying the holy objects outside consecrated ground. In political rituals a distinction could be made between statutory acts (taking the oath, judgements, granting charters, elections) on one hand and, on the other, glorifying ceremonies in the form of entrances and rituals of submission.

\section{PROClamation}

The public nature of the ritual exposed the relations between prominent figures known to the entire community. Everything happened in public places; insofar as these were not, or only partially, accessible, there had to be a time for public presentation. In this way, the new relations became binding in a political sense, no less for the subjects than for the rulers. Sometimes it was no more than a corroboration of an already existing good relationship. A ruler who was not received with suitable marks of honour, formal toasts in wine and gifts by a town through which he happened to be passing, would have sufficient reason for displeasure. Similarly, a town that could not boast of such a visit would have cause to worry about disrupted relations. Any breach in the normally reciprocal 'love' had to be repaired as soon as possible. Symbolism was used time and again to make these relations publicly visible, so that everyone was well aware of them.

Ritual humiliation, inspired by feudal and church symbolism, followed the subjection of a rebellion. Those who were to be punished had to dress as penitents: they were stripped of their honourable clothing and made to appear bareheaded and barefoot in their undershirt, and ungirded; they were obliged to beg the triumphant ruler for mercy, which he would only grant after the triple insistence of a religious intercessor. The triumph of Duke Philip the Good over Ghent in 1453 can be regarded as the most elaborate ritual humiliation in the fifteenth century: it was not by chance that this scene was represented in the form of an exquisite miniature. ${ }^{18}$ In

\footnotetext{
${ }^{18}$ E. Dhanens, 'Het Boek der Privilegiën van Gent', Academiae Analecıa. Mededelingen
} 
1540 Charles $\mathrm{V}$ added yet another element by putting a noose round the neck of the penitents to symbolize the capital punishment they actually deserved for their part in the uprising. Humiliation, reconciliation and elevation to a new dignity were increasingly shown in public by visual means and signs. In this way, and without many words, which in any case would have been lost in such a large, open-air gathering, the relative positions of ruler and ruled were made perfectly clear to everybody.

\section{AFFIRMATION OF SUPPORT}

In our view, the performance of a sacral or judicial act and its visual execution did not exhaust the functionality of political rituals. Members of the public who attended were expected to be more than just passive observers: they were expected to feel involved and to express their support. This could be done at suitable moments by decorating the town and cheering the entry of their ruler. In 1301 the people of Bruges maintained a purposefully icy silence during the entry of King Philip IV of France. No one could fail to notice the political message, 'at which, it is said, the king was much surprised'. ${ }^{9}$ The invitation to 'the people' to show their approval of the coronation of the king in the cathedral of Rheims may be strongly ritualized, but it can still be distinguished from the liturgical activities. ${ }^{20}$ In the same way, until the beginning of the fourteenth century, representatives of the people of Venice shouted out their approval of the election of a doge with a triple fiat. ${ }^{21}$ The swearing of the oaths of homage, both in the great market squares of Flanders and Brabant, and on a hillside in the dunes as was the custom of the Kennemerland peasants until $1478,{ }^{22}$ implied the assent of the massing crowds. True, in both cases, it was but a

van de Kon Academie voor Wetenschappen, Klasse der Schone Kunsten 48 (1987) 91 112, J C Smith, 'Ventt nobıs pacificus Dominus Phılı the Good's Triumphal Entry into Ghent in 1458', in B Wisch \& S S Munshower (eds), 'All the World's a Stage 'Art and Pageantry in the Renaissance and Baroque Papers in Art History from the Pennsylvania State University VI (1990) 259-90

${ }^{19} \mathrm{~F}$ Funck-Brentano (ed), Annales Gandenses (Parıs 1896), H Johnstone (ed and transl ), Annals of Ghent (New York 1951) ch 13

${ }^{20} \mathrm{~J}$ Le Goff, 'A Coronation Program for the Age of Saint Lous, the Ordo of 1250', in. J M Bak (ed), Coronations Medieval and Early Modern Monarchic Ritual (Berkeley 1990) 46-57

${ }^{21}$ E. Murr, Crvic Ritual in Renaissance Ventce (Princeton 1981)

${ }^{22} \mathrm{~J} \mathrm{G} \mathrm{Smit,} \mathrm{Vorst} \mathrm{en} \mathrm{onderdaan} \mathrm{Studies} \mathrm{over} \mathrm{Holland} \mathrm{en} \mathrm{Zeeland} \mathrm{in} \mathrm{de} \mathrm{late}$ middeleeuwen (Leuven 1995) 232 
ritual confirmation of decisions negotiated and laid down by others: the peers of France, the Senate or the States General. Yet we should not underestimate such public manifestation as an instance of political importance.

With their theatrical character the public ceremonies not only affected the cognitive dimension of the communication between the ruler and his subjects, they were also aimed at creating or strengthening an emotional bond. The reactions of the highly placed guest were observed closely, and signs of appreciation and regard highly prized. In this way the ritual itself again generated political power, the paternal love which bound the ruler to his subjects.

The rites of passage of the royal dynasty usually had a purely confirmative significance. Organization was the responsibility of the court, which also bore most of the costs. Since a town was always the setting for the event, and the local populace was naturally present, such happenings once again fulfilled a political function. These happenings were really addressed to the distant worlds of other courts, which reports from ambassadors and travellers kept informed of the lustre attaching to a particular ceremony. Burgundian royal marriages were celebrated with special splendour, beginning with the double marriage with the house of Bavaria at Arras in 1385, followed by Bruges in 1430 and 1468, Ghent in 1477 , and Lier in 1496. Funerals and the transport of mortal remains from the Netherlands to Dijon, as happened in 1405 and $1473,{ }^{23}$ allowed for less variety. On occasions like these - such as the funeral of Philip the Good in Bruges in 1467 - we notice the extreme care given to the hierarchic composition of the procession. At the head of the procession walked the clergy and magistrates of Bruges and the Brugse Vrije (the large rural district in West Flanders), followed by courtiers in ascending hierarchy, then four bishops and 22 abbots, 24 officials bearing the duke's escutcheons, the coffin covered with a shroud of cloth of gold and accompanied by the sword of the deceased duke, carried by his high marshal. Next came members of the family. ${ }^{24}$ Marriage, baptism and mourning provided an excellent opportunity for the subjects to express their emotional bond with the dynasty, in spite of their passive role in the

\footnotetext{
${ }^{23}$ R. Vaughan, John the Fearless (London 1979) 1-2; W.P. Blockmans (ed.), Handelingen van de Leden en van de St.tten van Vlaanderen (1466-1477) (Brussels 1971) 193-8.

${ }^{24}$ R. Vaughan, Charles the Bold (London 1973) 1-2.
} 
events ${ }^{25}$ In a just somewhat lower rank, the pattern of the rituals was modelled along the example given by the princes In 1482, a funeral ceremony was organized at Enghien for Pierre de Luxembourg, count of Saint-Pol, who had been interred a few days earler in the abbey of Cercamp The procession was equally constructed in an ascending hierarchy, starting with the balliff, the court officials, then the councillors, the knights, and the heralds, then followed the deuil, the family The order of precedence, which had not been established without discussions, was based on the proximity of the lineage, not on the rank of nobility Quantıfication of the family's material investment in the ceremony was a matter of public interest ${ }^{26}$

\section{SYMBOLIC COMPETITION}

A more far-reaching form of participation by the subjects was their assistance in the production of the spectacles themselves This could include appearing in the procession and organizing theatrical presentations Out of this came the fourth function of public rituals In the course of time a certain amount of competition grew up between the districts, guilds, rhetoricians' chambers and brotherhoods in the towns, and between the towns themselves In the fifteenth century this led to contests being held regularly in the case of the miltias and rhetoricians Considering the prominent role of these organizations in arranging public festivities it is natural to suppose that they sought innovation and excellence in their production A high point in this area was achieved in 1516 On the occasion of the death of King Ferdınand of Aragon, grandfather of the future Emperor Charles V, a funeral procession went through Brussels, the climax of which, in the absence of the body, was a triumphal carriage in the form of a ship Designed by Jan Gossaert, it was the first of its kind in

\footnotetext{
${ }^{25}$ A Chevalıer, 'Le Brabant a l'aube du XVe srecle fêtes et solemnites a la cour des ducs de la branche cadette de Brabant Valors (1406-1430) Le mariage d Antone de Bourgogne et d'Elisabeth de Goerlitz', Publication du Centre europeen d Etudes bourgutgnonnes 34 (1994) 175 86, M Somme, Le ceremonial de la na1ssance et de la mort de l'enfant princier a la cour de Bourgogne du XVe siecle', ıbid, 87-103, B Schnerb 'Un service lunebre celebre pour Jean sans Peur a Sant-Vadst d'Arras le 22 octobre 1419', ibıd, 10522 For the baptısm reremontes in Bruges in 1478, see W Preventer \& W Blockmans, The Burgundian Netherlands (Cambridge/Antwerp 1986) 198

${ }^{26} \mathrm{P}$ Contamine, La noblesse au Royaume de France de Phllppe le Bel a Lous XII (Parıs 1997) $290-3$
} 
the Low Countries. Four suits of armour were displayed on the forward deck, symbolic of the king's victories; in the centre stood a warrior with an unsheathed sword, behind was the dead king's empty throne. Belonging to the same tradition was the ship Victoria which was included in the long cortège for Charles V in Brussels in 1558, and which still appeared in joyous entries and processions in 1596 and $1615 .^{27}$ The choice of symbols belonging to different semiotic systems expressed the tensions between Charles $\mathrm{V}$ and Pope Paul III at the occasion of the latter's entry into Rome. ${ }^{28}$

In conclusion, we can see four functions for these public rituals: the execution of an important sacral or statutory act, making that known, fostering the mutual, emotional bond between subjects and between subjects and their rulers, and finally, the manifestation of artistic competition between urban communities.

\section{Order of Precedence}

At public occasions people of the Middle Ages set great store by the order of seating, rank and precedence which made visual the constitution of their hierarchic society. Clothing, behaviour and the number of followers had to be in accordance with one's place. Every list was based on this and thus kept reaffirming the relative position of individuals and groups. Changes in the ranking order had to be shown publicly, but mostly they had to be fought for against the vested positions. Any attempt to rise in the ranking order meant a possible blow to those already in place, the honour of whom was thus challenged. Rhetoric as well as physical violence often ensued in order to preserve or redefine each contender's position. ${ }^{29}$ At court, ordinances regulated everyone's place and share in minute detail. These were reviewed regularly and amended according to changing circumstances. ${ }^{30}$

\footnotetext{
${ }^{27}$ R.W. Scheller, 'Jan Gossaerts Triomfwagen', in: Essays in Northern European Art Presented to Egbert Haverkamp-Begeman (Doornspijk 1983) 228-36.

${ }^{28}$ Andreas Rüther, 'Imperial Self-Representation. Charles V's Procession into Rome in April 1536', in: Gosman, Vanderjagt \& Veenstra, Propagation of Power, 327-43.

${ }^{29}$ K.-H. Spiess, 'Rangdenken und Rangstreit im Mittelalter', in: W. Paravicini (ed.), Zeremoniell und Raum (Sigmaringen 1997) 39-61, esp. 45-8.

${ }^{30}$ W. Paravicim, 'Die Hofordnungen Herzog Philipps des Guten von Burgund. Edition', Francia 10 (1982) 131-66; 11 (1983) 257-301; 13 (1985) 191-211; 15 (1987) 183-231; 18 (1991) 111-23; in his article 'The Court of the Dukes of Burgundy', 108, he quotes later ordinances.
} 
Even then, the complexity of the rules of precedence and deference left some room for conflicting interpretations Intentional breaking of the rules might have occurred as well, as a demonstration of sympathy by the higher ranking person or as a means to escape insoluble status conflicts

In July 1411, John the Fearless was given leave to rase a force of 10,000 men immediately there was dissension between the Vier Leden of Flanders (Four Members, 1 e Ghent, Bruges, Ypres and the Brugse Vrue) over the precedence of therr troops In 1414, Duke John the Fearless himself would fight his own struggle of precedence with King Charles of Navarre which was solved only by the compromise that they would share the same rank, alternatıng sides ${ }^{32}$ Each of the Four Members was desirous of making an impression through the good appearance (scoenen state) of its own forces and those of its subordinate towns and territories There was also a quarrel between Bruges and the Brugse Vrue about demarcation of precedence When that was solved the question arose of whether the Brugse Vrue or Ypres and its contingent should march directly behind Bruges After all, the town of Ypres was the third Member of Flanders and the Brugse Vrye the fourth, the latter produced the argument that each one should follow behind its capital, which was again agreeable to Bruges Five weeks of negotiation with the duke and his council were necessary merely to achieve a simple, unprejudicial compromise the men of Ypres and those of the Brugse Vrije would take precedence on alternate days ${ }^{33}$ This inc1dent, which was to be repeated when the local armies were mobilized again in 1436, shows the importance that was attached to a fitting position for all participants in a public event, certainly in the presence of the ruler It was not without reason that each unit carried its own banner and was dressed in a distinctive livery to make its membership in a particular community clearly visible

In the States General there were disputes in 1501, 1508 and 1552 about the order of rank of representatives from the two largest principalities, Brabant and Flanders The latter was economically stronger and had a much larger population, but it had to give precedence to the dukedom of Brabant which was higher placed in the hierarchy of principalities

\footnotetext{
${ }^{31} \mathrm{~J}$ Paviot Les marques de distance dans les Honneurs de la Cour d'Alienor de Poitiers', in Paravicin, Zeremontell und Raum, 916

${ }^{32}$ Paviot, 'Marques de distance', 92-3

${ }^{33}$ Vaughan John the Fearless, 143, A Zoete (ed), Handelingen van de Leden en van de Staten van Vlaanderen (1405 1419) I (Brussels 1981) 576-78, 583 95, quote from 585 I 31
} 
Nevertheless, the Flemings insisted that a pensionary from Ghent or Bruges be spokesman for all the representatives when the assembly took place in their city. ${ }^{34}$

Analogously with what was happening outside the town walls, hierarchies were much in evidence within the town. Aldermen constituted boards of often seven or thirteen members, whose places were ranked carefully and divided according to the echelons of the populace. This hierarchy was strictly observed, both in the sequence of the seating and in the written listings of the officials. At the level of the craft guilds in the towns, hierarchy was a sensitive question. It is typical of the situation that in 1429 seven Ghent guilds had a dispute about the order in which they would walk in the annual Blessed Sacrament procession of the parish of St. Nicholas. This sequence had to coincide precisely with the annual registers of the deans of the 53 minor guilds; it is a striking example of how people insisted that the procession should reflect the actual order of precedence. ${ }^{35}$

Some chronicles contain descriptions of the composition of the processions welcoming rulers into the cities. The picture of the corporate composition is very clear in these descriptions, since all the groups were recognizably listed. For the entry of Philip the Good into Bruges during Advent 1440, for example, the nations of foreign merchants were listed along with their exact number of participants. ${ }^{36}$

The chronicle by Jean Molinet provides an enthusiastic description of the procession held in Ghent on the occasion of the baptism of Prince Charles, on the evening of 7 March $1500 .{ }^{37}$ The citizens made every possible effort to celebrate this occasion with great triumph ('à grant triumphe'). On the river, a ship carrying the city's clarions was ornamented with six or seven hundred burning torches. The great novelty was a rope-walk hanging between the spire of the Belfry and that of the church of St. Nicholas, from which torches and lanterns illuminated the city. The dragon on the Belfry spewed fireworks from its mouth and tail. The citizens had constructed a three-foot-high walk linking the castle to St. John's church. Three times

${ }^{34} \mathrm{R}$. Wellens, 'Le droit de préséance dans les assemblées des Etats Généraux des PaysBas au XVe siècle', Anciens Pays et Assemblées d'Etats 47 (1968) 113-47.

${ }^{35}$ M. Boone, Gent en de Bourgondische hertogen ca. 1384 - ca. 1453 (Brussels 1990) 75-78.

${ }^{36}$ Nicolaas Despars, Cronijke van den lande ende graefscepe van Vlaendren (ed. J. de Jonghe) 4 vols. (Bruges 1837-40) III 431-2.

${ }^{37}$ G. Doutrepont \& O. Jodogne (eds.), Chroniques de Jean Molinet, ch. 288, vol. 2 (Brussels 1935) 468-71. 
thirteen gates marked the route. They were decorated with the prince's arms and with torches. Three major gates were named Wisdom, Justice and Peace.

The chronicler carefully noted the order of the procession: first the deans of the guilds 'with their people', then the aldermen, then the city's knights and noblemen, all holding a torch; then followed the noblemen of the princely household, escuyers, knights, councillors, knights of the Order of the Golden Fleece. After these came the lords, princes and princesses of the blood. Molinet stressed repeatedly the high cost of the celebration and described in detail the gifts offered to the newborn prince. He noted that the city must have supplied 10,000 torches, to which had to be added the decorations by individuals. One silk merchant was said to have draped his house with cloth, velvet and damask and to have thrown an abundance of money to the people. Obviously, the city not only provided the scenery for the show, the people participated in it intensely. The celebration offered an occasion for both the court and the city, including individual burghers, to demonstrate their wealth and their close relations. Coming less than eight years after Ghent's rigorous submission, which followed upon ten years of revolt, this can be called a major political achievement.

We know of only one series of illustrations of an entry procession from the fifteenth century. It contains a description in short texts and 60 drawings of the procession with which Joanna of Castile entered Brussels on December 9, $1496 .^{38}$ She had arrived at Middelburg on September 19, and was married in Lier on October 20. While she was making her entry into Brussels, her consort, Archduke Philip the Handsome, was negotiating with the States General in Breda. ${ }^{39}$ The reception of the princess consort had no constitutional significance, and was purely and simply a goodwill operation. The whole production was focused on her person, presented in the tradition of heroic, most Christian monarchs. The illustrations form part of a manuscript that originally must have consisted of 64 folios, the

\footnotetext{
${ }^{38}$ Berlın, Kupferstichkabınett, 78 D 5, $356 \times 250$ Description. P. Werscher, Beschretbendes Verzeignis der Miniaturen - Handschriften und Einzelblatter - des Kupferstichkabınetts der staatlıchen Museen Berlin (Leipzig 1931) 179-81; the theatrical tepresentations have been studied and partly ieproduced in M. Hermann, Forschungen zur deutschen Theatergeschichte des Mittelalters und der Renatssance (Berlın 1914) 367 409.

${ }^{39} \mathrm{H}$ Wiesflecker, Kauser Maximilian I, vol. II (Munich 1975) 41, R. Wellens, Les Etats généraux des Pays-Bas, des orlgines à la fin du règne de Philippe le Beau (1464-1506) (Heule 1974) 238 ff.
} 
last of which, with an illustration of the town hall in Brussels, has been lost ${ }^{40}$ Sixty diawings survive, painted in water-colours, and produced rather superficially and stereotypically The left-hand pages contain a short description of the show in Latin The text contains quite a number of contemporary corrections Produced on paper, it is not a particularly beautiful manuscript, but it has a unique iconographical value Not only is it, up till now, the oldest-known series in Europe, containing 30 lllustrations of an entry procession, ${ }^{41}$ it also shows 27 pictures of the tableaux vivants which were arranged along the route The text focuses constantly on the princess, and warmly recommends the city of Brussels to her person It was most probably pioduced by the organzers of the reception, $1 \mathrm{e}$, the town councillors in co-operation with the chamber of rhetoric and the guild of St Luke The city was more than clearly represented in the first and last drawings, respectively the archangel Michael, the patron saint of Brussels, and the missing, but fully described, drawing of the town hall The central drawing, on $\mathrm{f} 31$, also shows the princess in front of the town hall which was illuminated by torches The first and last drawings in the series of the tableaux vivants seem to be equally significant they show Tubal, the biblical father of music, and St Luke painting the Virgin We can interpret these pictures as identifying wilh, respectively, the chambers of rhetoric ${ }^{42}$ and the guild of painters, jointly responsible for organizing the reception The last drawing was followed by two pages of coats of arms, the joint arms of Philip and Joanna (including the not yet official union of Castile and Aragon), and the arms of all Philip's domains All these signs of identification support our hypothesis that it was the host city of Brussels that presented the manuscript as a gift to the princess on her entry, to explain the images that had been pioduced for her, and also ds a keepsake Because of the relatively short time avallable for preparation this manuscipt fell short of the very high standaids of book production in the Netherlands Its contents, and the connection with the entry of the princess, however, made it an original, unıque and royal gift

The procession is pictured in 29 drawings, grouped in related sections The construction is herarchic from low to high, beginning with the lower clergy and ending with the princess

\footnotetext{
${ }^{40}$ The manuscript is composed of eight sections of sixteen pages, of which the last is missing On $\mathrm{f} 631 \vee$ an extensive description announces the following illustration

${ }^{41}$ Compare the tacsimile edition by $S$ Anglo La tryumphante Entree de Charles prince des Espagnes en Bruges 1515 (Amsterdam/New York n d)

${ }^{42}$ Around 1500 Brussels had four rhttoncians' chambers, all Dutch-speakıng, see H PleIj, De sneeuwpoppen van 1511 (Ansterdam 1988) 187
} 
1. Six groups of clergymen, scholastics, Carmelites, the Friars Minor, priests, canons and the chapter of St. Gudula, all in order.

2. Two basic groups of townspeople: the hundredmen representing townspeople from the various neighbourhoods, and craft guilds, all with torches and their coats of arms.

3. Six entertainments: three fools and a fat monk making music, a buffoon being mocked by young boys, an Ethiopian princess on a white horse accompanied by savages, a fool sitting the wrong way round on a chair on a horse, savages fighting, and masked bagpipers on a sleigh.

4. Ten (with the two mentioned in no. 2 making a total of twelve, as many as the preceding twice six) groups representing the town, all mounted: young men, 'clients', eight servants, eight peacemakers, eight judges, six secretaries, six councillors, six receivers, the aldermen, the mayor.

5. Five groups of guild members, bearing torches, on foot, the last of whom were crossbowmen accompanying the princess on her horse.

This structure presents an image of the urban community as its elites wanted it to be seen: an organic whole consisting of different parts, hierarchically ordered but working harmoniously together. A procession was one way of bringing this image home to all the people. Everyone played his part, in his appointed place, in full view of everyone else.

\section{Messages}

Clothing and heraldic emblems were the most conspicuous visual signs making social identification possible. Both were combined in liveries with heraldic colours. The town's communities had adopted this usage from the world of chivalry. The town council even took over seals, coats of arms and banners, as did the craft guilds in their turn. The originally military function of the guilds was a good reason for adopting the accepted identifying marks. From the twelfth century the city militia of Milan had itself represented with its banners. ${ }^{43}$ Early in the fourteenth century the guilds of Ghent graced the famous woodcarving of the Battle of the Spurs on the socalled Oxford chest, and the murals of the Leugemete in Ghent dating from $1346{ }^{44}$ They were later used frequently even in the decoration of the

\footnotetext{
${ }^{43}$ Milan, Museo Sforzesco.

${ }^{44}$ B. Dewilde, A. Pauwels, J. Verbruggen \& E. Warlop, De Kist van Oxford (Kortrijk 1980) reprint from De Leiegouw XXII (1980) 163-256; M.P.J. Martens, De muurschilderkunst te Gent, XIIde tot XVIde eeuw (Brussels 1989).
} 
Council Chamber in the town hall in Ghent, dating from 1483, and in the frame of the panoramic view of Ghent made by Pieter de Keysere in 1524. It is interesting that even here the guilds' traditional order of rank was followed precisely. ${ }^{45}$

The use of banners was so sensitive that they were repeatedly the subject of fierce controversy between the ruler and guild members. In 1407 Duke John the Fearless regulated the use of guild banners in Bruges: on no account were they to be shown in popular gatherings or elsewhere without the express order of the duke, his steward or bailiff. The banner of the duke was to be unfurled in the main square before one of the guild banners could be shown. Any infringement would be punished as a conspiracy, by execution in front of the Great Hall and confiscation of all possessions. Even if one or more guild members were to raise the flag for a meeting on the authority of their dean, they would forever lose all rights to a banner. ${ }^{46}$ During the Ghent uprisings later in the fifteenth century banners proved to be the perfect means of rousing people, urging them to join the public gatherings at the Friday market. In 1453 and 1469 the dukes confiscated the guilds' banners for this very reason: the guilds thus lost the most visible and functional signs of their identity. ${ }^{47}$

The symbolic communication between ruler and subjects went much further than the manifestation of a relatively autonomous group identity. A very extensive iconographical and theatrical programme contributed to the emotional restoration of good relations, especially when a ruler visited a town for the first time after putting down an uprising. In December 1440, after its subjection in 1438, Bruges welcomed Philip the Good during Advent, using all the symbolism connected with the coming of the Messiah. The tableaux vivants showed a synthesis of themes from punishment, on entering the city gates, to the expectation of mercy on the part of a ruler who is held in honour by his people. ${ }^{48}$

\footnotetext{
${ }^{45}$ B. Bailleul \& A. Duhameeuw, Een stad in opbouw. Gent voor 1540 (Tielt 1989) 206-21.

${ }^{46}$ Vaughan, John the Fearless, 27; L. Gilliodts-Van Severen, Inventaire des Archives de la ville de Bruges, IV (Bruges 1876) 14-16.

${ }^{47}$ P. Arnade, 'Crowds, Banners and the Marketplace: Symbols of Defiance and Defeat During the Ghent War of 1452-1453', Journal of Medieval and Renaissance Studies 24 (1994) 471-97; id., Realms of Ritual. Burgundian Ceremony and Civic Life in Late Medieval Ghent (Ithaca/London 1996) 95-i26.

${ }^{48}$ G. Kipling, Enter the King: Theatre, Liturgy and Ritual in the Medieval Civic Triumph (Oxford 1998); J.M. Murray, 'The Liturgy of the Count's Advent in Bruges, from Galbert to Van Eyck', in: Hanawalt \& Reyerson, City and Spectacle, 137-52.
} 
The same duke's reception in Ghent, in 1458, five years after its subjection, was associated with even more theatrical and rhetorical effects. On St. George's day - St. George was one of the patron saints of the dynasty he was welcomed under the motto based on Judith 3:3 'Come unto us peaceloving Lord and use us as it pleaseth thee'. Speeches and theatrical presentations in French and Dutch, and naked sirens swimming around seaknights fighting in the Lys expressed the burning desire of the people of Ghent for a compassionate duke. The council had awarded prizes to encourage the townspeople to make extraordinary efforts to decorate their town and devise the loveliest performances. ${ }^{49}$

A spirit of rivalry developed between the towns for the most splendid reception of the duke. The week-long celebrations round the marriage of Charles the Bold and Margaret of York in Bruges in 1468 drew the eyes of all Europe and reports were written and distributed in many languages. The court chronicler, Olivier de la Marche, made a detailed description of the events, as did the knight Jean de Haynin. One eyewitness produced a report in Latın, a summary of which, including a full description of the dishes served, could be found in German in the town chronicle of Stuttgart. An account in English was reprinted three times. The town rhetorician, Anthonis de Roovere, wrote a short chronicle in Dutch about the events he witnessed and helped to organıze. His text was sent to the mayor of Lubeck. ${ }^{50}$ He must have been in contact with Olivier de la Marche from whom he drew inside information unavailable to himself. His Excellente cronike van Vlaendren, of which no fewer than seven contemporary copies in a West-Flemish dialect circulated at the time of his death in 1482, contained an abbreviated version of this episode. ${ }^{51}$ In view of such publicity this can truly be seen as a media event.

\footnotetext{
${ }^{49}$ E Dhanens, 'De Blijde Inkomsi van Filips de Goede in 1458 en de plastische kunsten te Gent', Academiae Analecta Mededelingen van de Kon Academie voor Wetenschappen, Klasse der Schone Kunsten 48 (Brussels 1987) 53-89, Smith, 'Vent nobis pacificus Dominus', N Mosselman, 'Les villes tace au prunce l'impoitance réelle de la cérémonie d'entrée solennelle sous le règne de Philıppe le Bon', in $\mathbf{J}$-M Duvosquel \& A Dierkens (eds), Vllles et Campagnes au Moyen Age Mélanges Georges Despy (Liège 1991) 533-48

${ }^{50} \mathrm{R}$ Vaughan, Charles the Bold (London 1973) 49, Ple1], Cocagne, 121, 166 For a tamous parnter's involvement in the princely ceremontes in Ghent 1467-77, see E Dhanens, Hugo van der Goes (Antwerp 1998) 73-9

${ }^{5} \mathrm{~J}$ B Oosterman, 'Anthonıs de Roovere Het werk de overlevering, toeschrujving en plaatsbepaling', Jaarboek van de Koninklyke Soevereine Hoofdkamer van Retorica 'De Fonteme' te Gent XLV-XLVI (1995-96) 29-140, esp 42-3
} 
Probably because of the rivalry with other cities, a written account was made of the joyous entry of Archduke Maximilian in Antwerp on the feast of the Epiphany in 1478; this account still survives. ${ }^{52}$ The city council offered cash prizes to groups of at least eighteen knights who would ride out to meet the prince, elegant and dignified ('sierlijcxt ende statelijcxt'), to nations, guilds and companies who would show the most beautiful and dignifred figures ('scoonste ende sierlijcxte figueren toonen soude'), or tableaux vivants, and to anyone who put on the best entertainment in the evening. Besides the unrestricted intiatives of the civic population the authorities themselves provided Latin quotations from scholarly literature which made the imperial patronage of the Church and the submissiveness of the chosen people known all over the world.

The city of Brussels went one step further with the production of the extensively illustrated manuscript described above, on the occasion of the entry of Joanna of Castile in 1496. The coherent construction of the scenes in combinations of the holy numbers three and twelve lead us to presuppose a tight organization. In all probability the structure of the manuscript reflected that of the procession and the tableaux vivants erected along the route. Twelve representations from the Old Testament showed heroic queens who stood up for their people. Thirteen mythological scenes were centred round the Nine Worthies (Neuf Preuses). ${ }^{53}$ Two representations referred to the past of the Trastamara dynasty, notably the conquest of Granada in 1492 by Joanna's parents, the Catholic King Ferdinand and Queen Isabella. For the sake of the cause only Isabella was depicted as victor. Finally, of particular note are the six entertainments, comic groups which may have formed part of the procession. They turned the world upside down, twisted formal relations with traditional motifs like the Ethiopian princess, savages, jesters, and a monk or chronicler being made a fool of. This ritual of reversal would have lightened the seriousness of the occasion and provided some comic relief, thus affırming the real order all

\footnotetext{
${ }^{52}$ Dr M Oosterbosch kindly provided us with the text of the document he intends to publish under the title 'De stad ontvangt een keizerszoon'

${ }^{53} \mathrm{H}$ Schroeder, Der Topos der Nine Worthes in Literatu' und Bildender Kunst (Gottungen 1971) 168-99, 250-6, W van Anroo1], Helden van weleer De Negen Besten in de Nederlanden (1300-1700)(Amsterdain 1997) 89-94, 158-79 A mote detalled desciuption of the pageants can be found in W Blockmans, 'Le dialogue imaginalie entre princes et sujets les Joyeuses Entrées en Brabant en 1494 et 1496', Publication du Centre européen d'études bourguignonnes (XIVe-XVle stècles) 34 (1994) 37-53, tepr in I -M Cauchies (ed), A la cour de B Jurgogne (Tunhout 1998) 155-70
} 


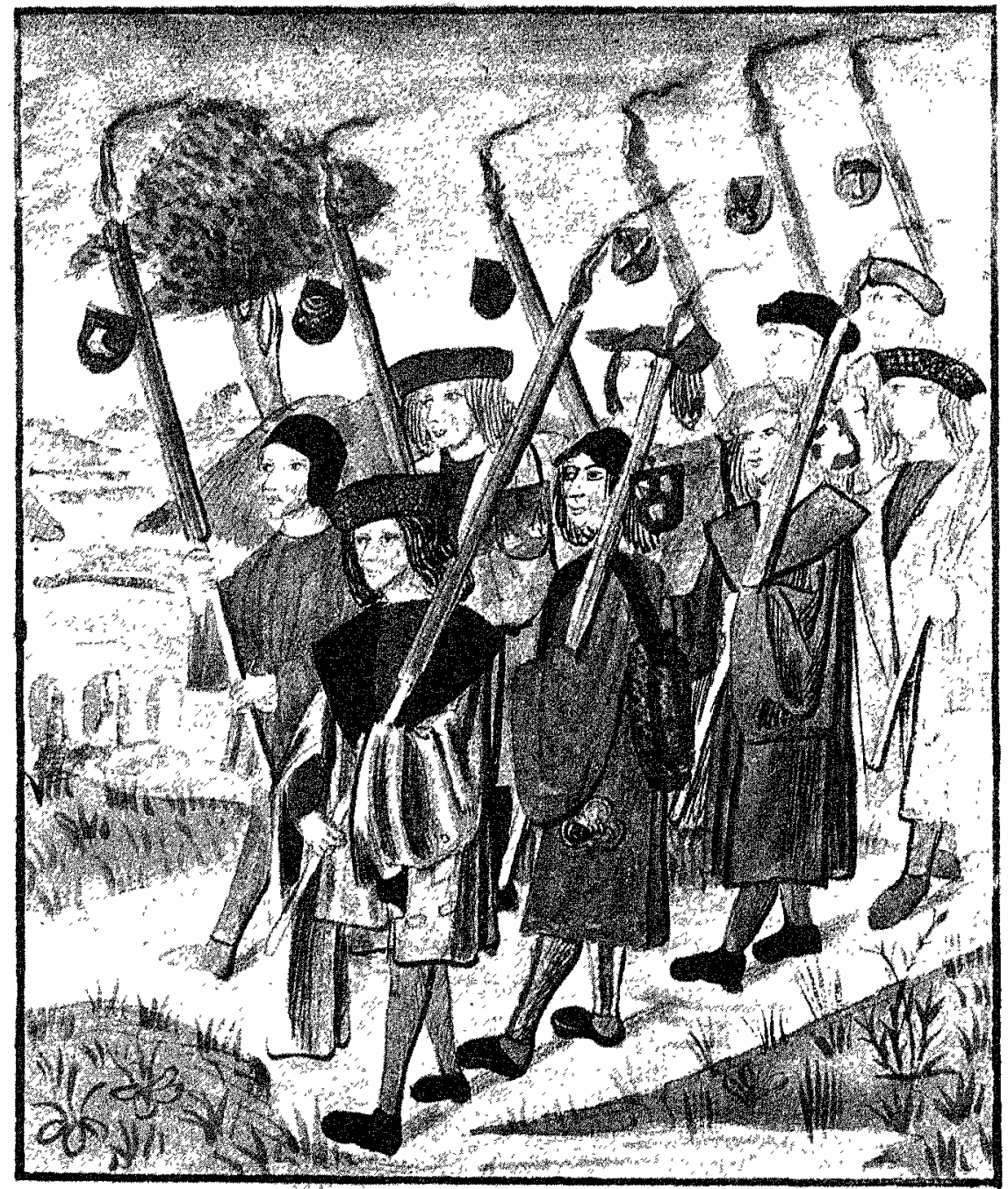

Figure 1. On the occasion of Princess Joanna of Castile's first entry in Brussels in December 1496, a manuscript was made containing 60 coloured drawings of the procession and the pageantry shown along its route. Brief comments in Latin explained the topicality of each subject. It opened with Brussels's patron saint, St. Michael, and closed with the coats of arms of Joanna and her spouse Philip of Austria. In the hierarchically constructed procession, the members of the guilds are shown bearing torches with their escutcheons. Berlin, Kupferstichkabinett SMPK, Ms. 78 D 5, f. 10. 


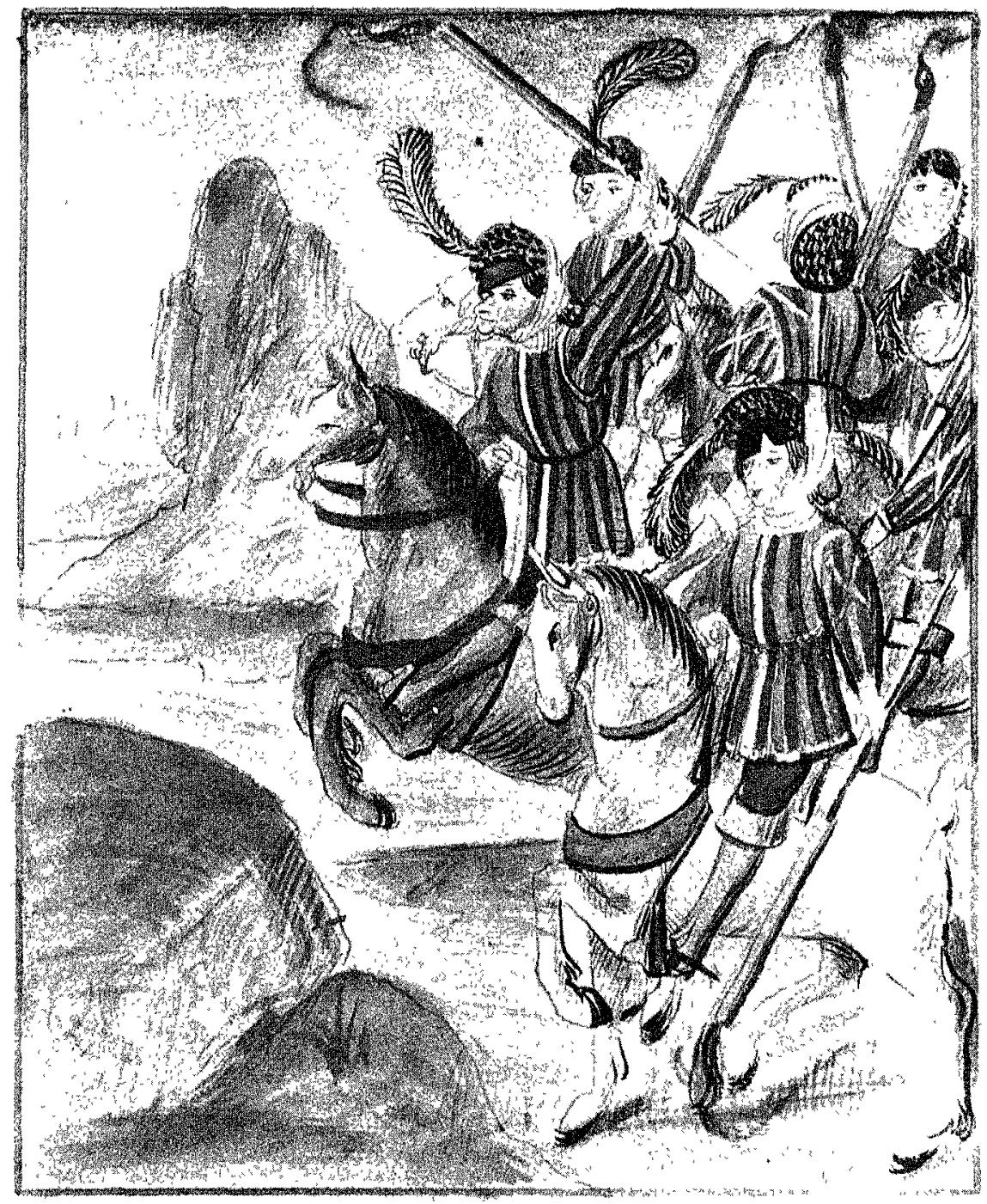

Figure 2. Mounted noblemen wielding torches (f. 17). 


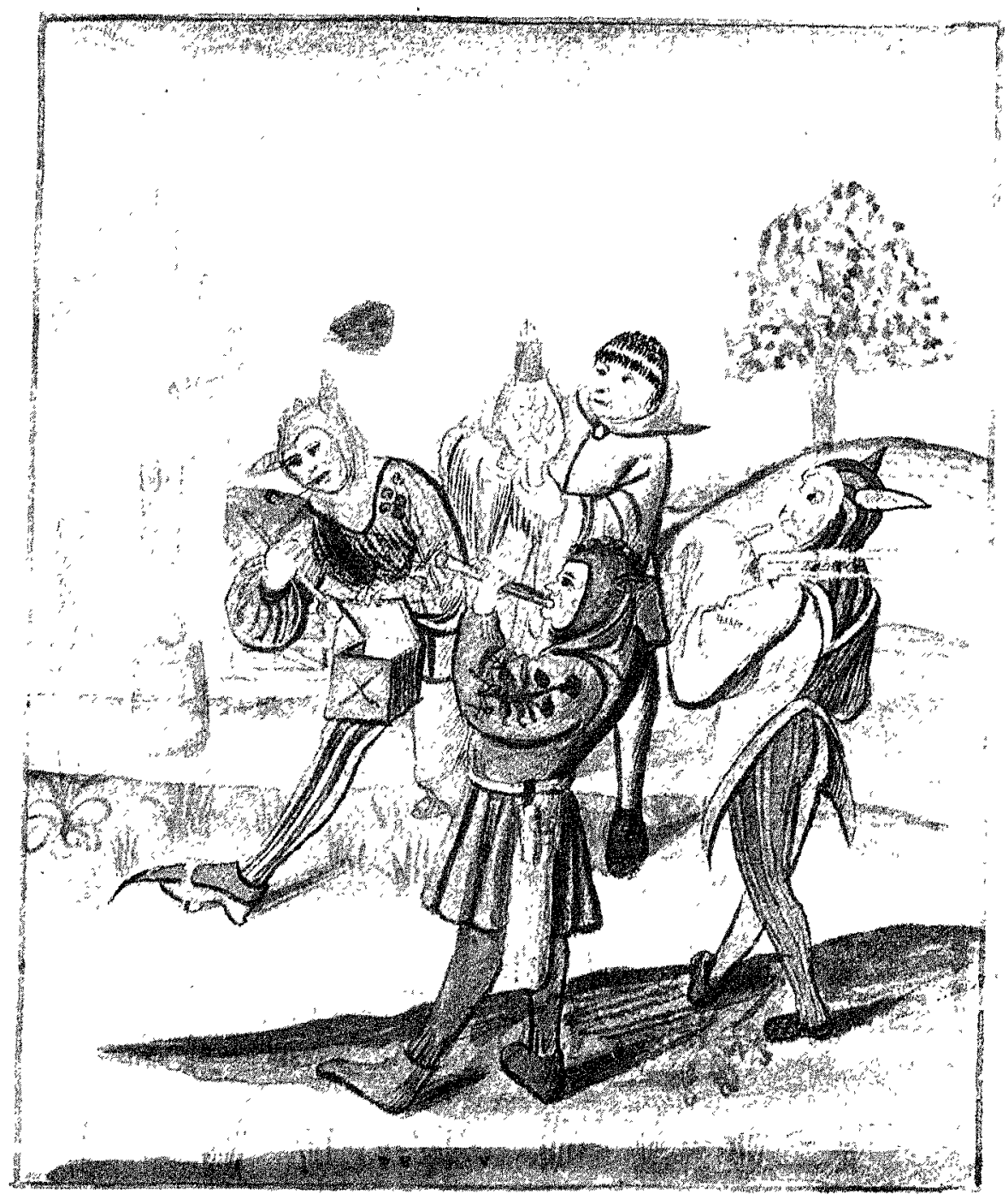

Figure 3. The solemnity of the procession of all the city's corporations was interrupted by six esbattements turning the world upside-down. A jester riding backwards on a donkey, or, as here, three jesters and a fat monk producing music, the latter with a bellows $(f . l 1)$. 


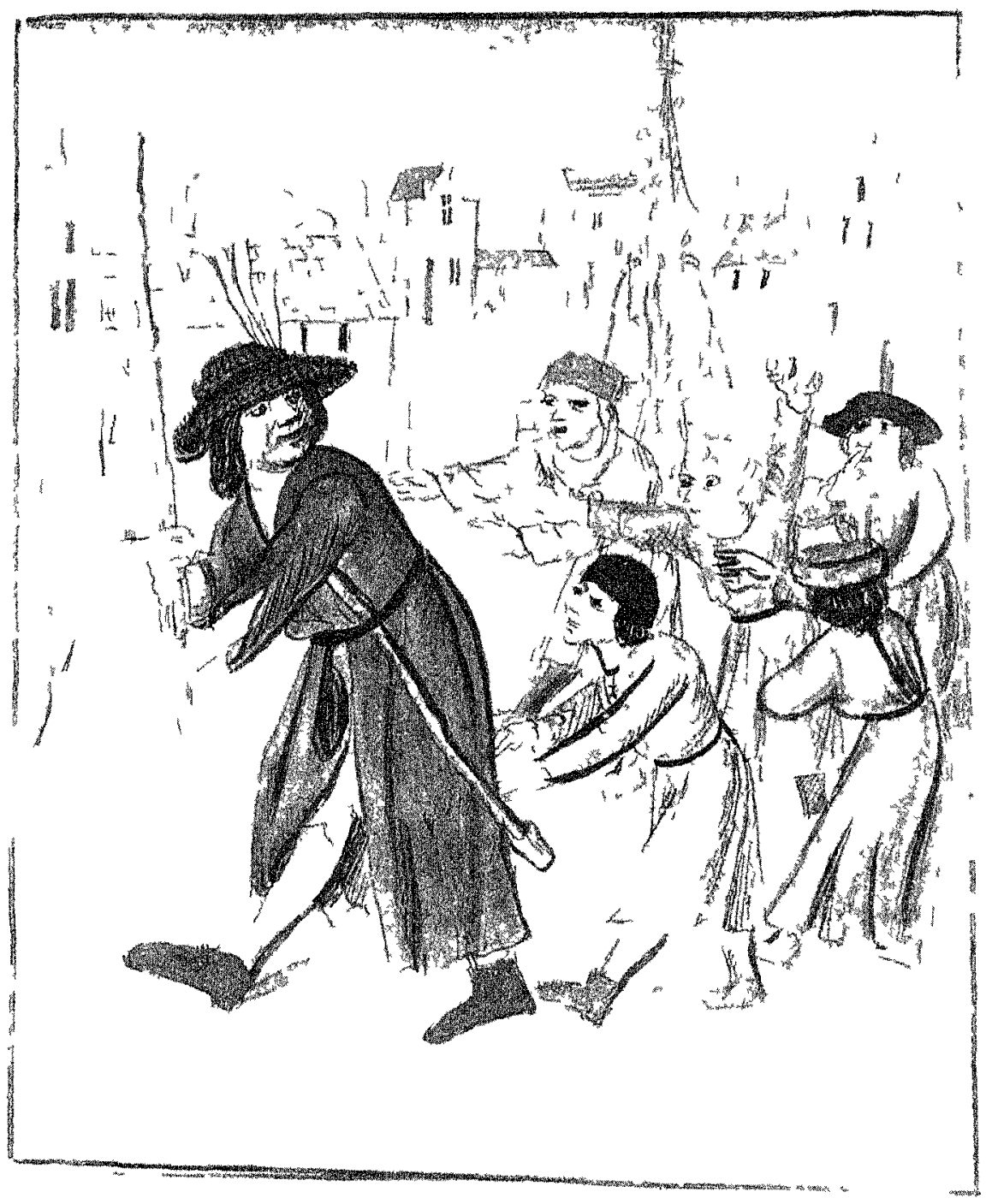

Figure 4 Histrio is being mocked by a boy (f 12) 


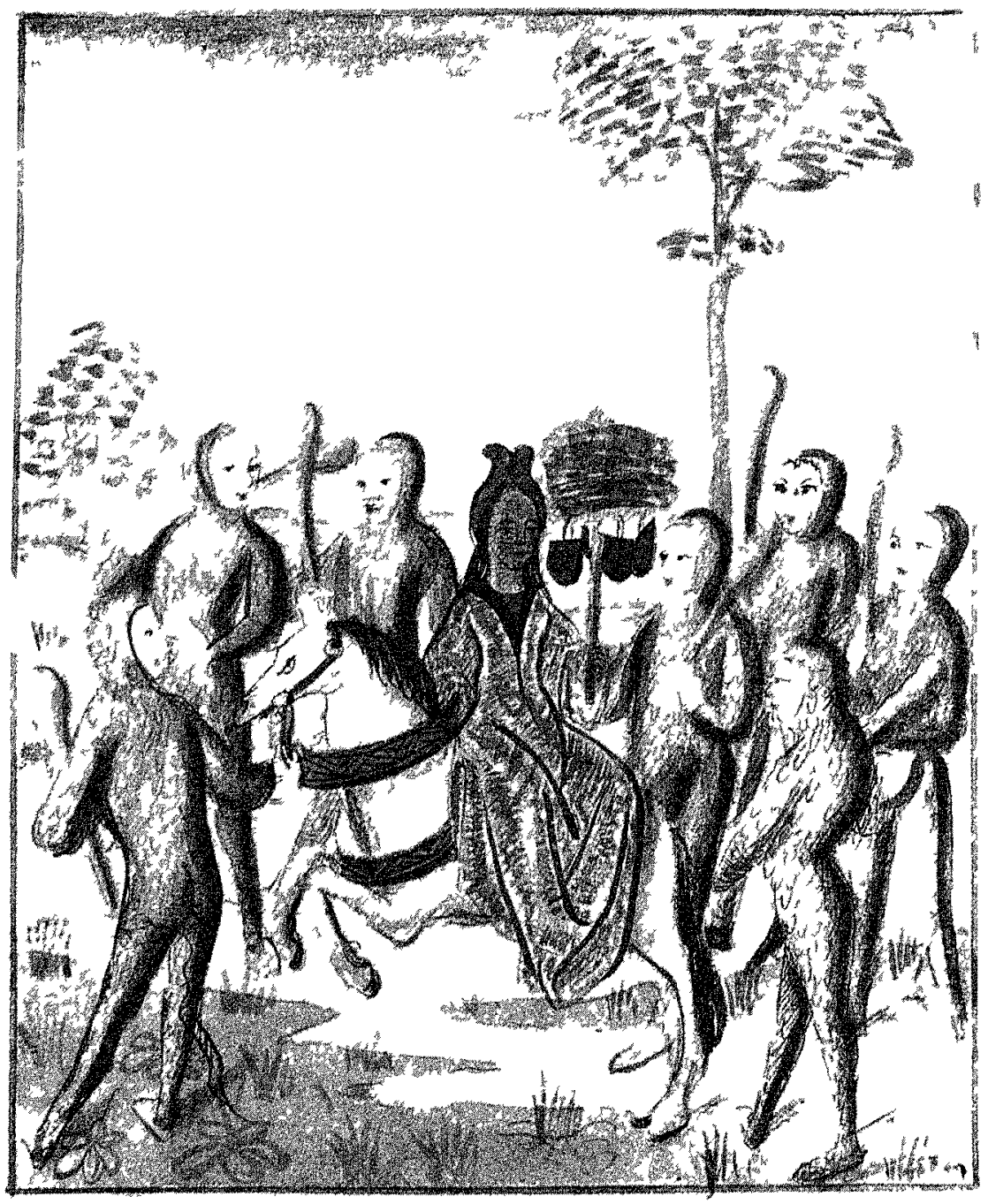

Figure 5 The black-faced Ethiopian princess on a white horse, accompanied by wild men attured in green and armed with clubs, clearly parodies the real princess further in the procession ( $f 13$ ) 


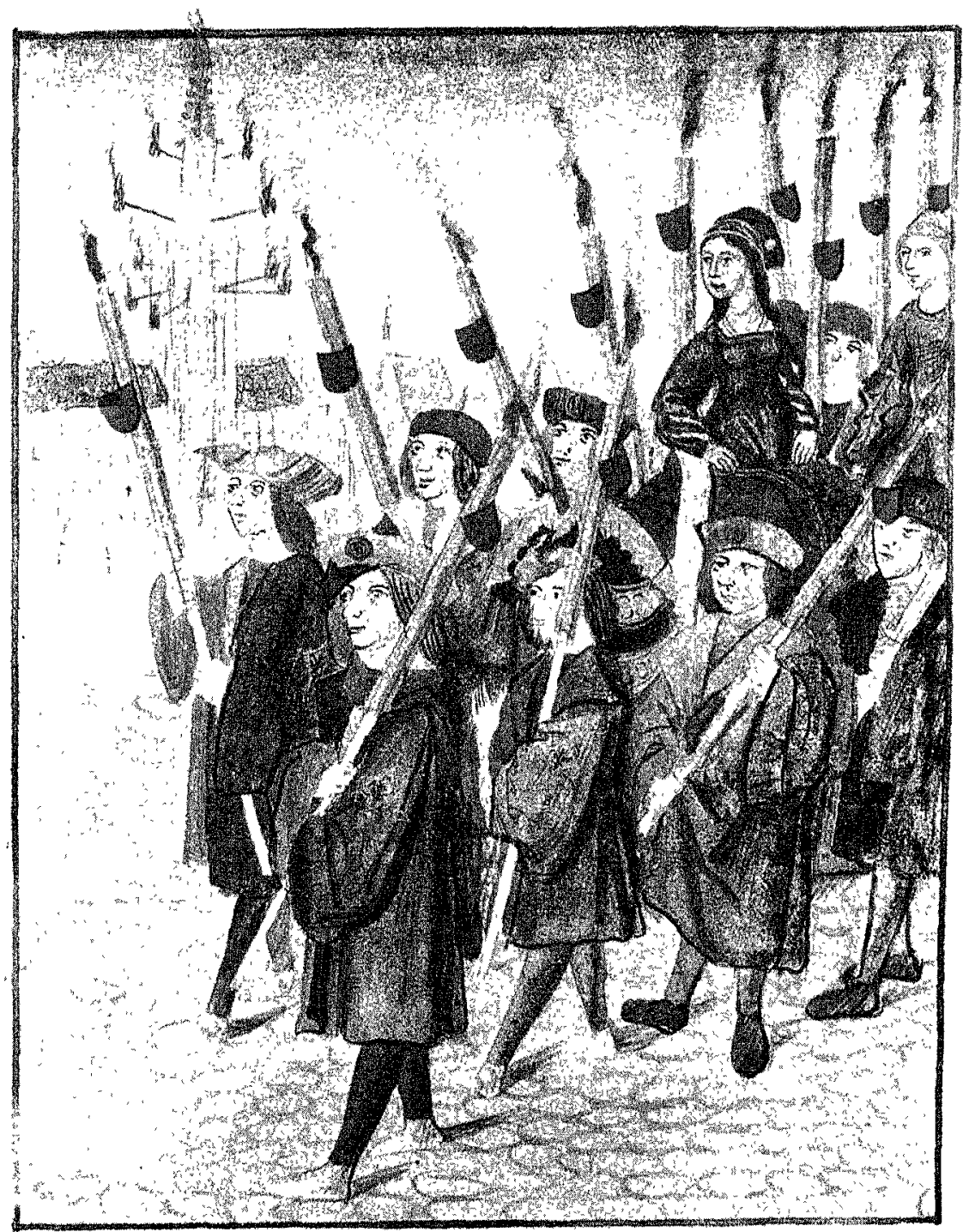

Figure 6. Princess Joanna on horseback escorted by the citizen soldiers. The town hall is illuminated by torches ( $f .31)$. 


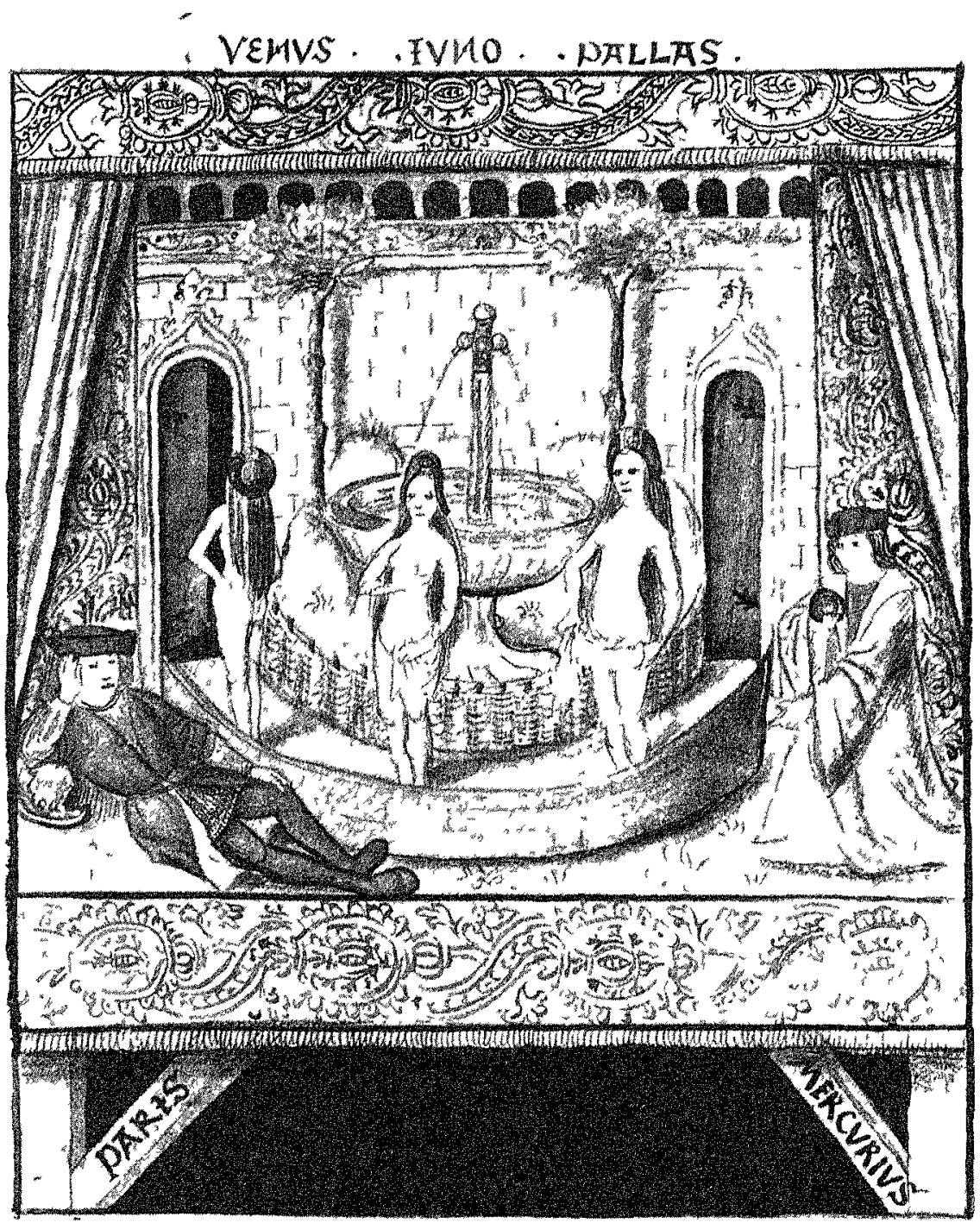

Figure 7. After fwelve Old Testament scenes showing warrior queens who fought for their people, thirteen mythological displays among which were the Nine Worthies, and two presentations alluding to the herotc past of the princess's dynasty, the climax of the tableaux vivants focused in three scenes on the joys of love and marriage. Here the Judgement by Parts, on a stage with the names of PARIS and MERCVRIVS (f. 57). 
the more clearly. All in all, in 1496 the city of Brussels manifested itself emphatically, while at the same time propagating the ideal image that it had formed of the new princess: a brave champion of her Christian subjects.

We also come across comical background figures in the pictures made of Prince Charles's entry into Bruges on 18 Aptil 1515. In this case even more steps were taken to publicize the event. Firstly, much trouble went into producing a manuscript, as had been done in 1496. From the introduction we know that it was produced by Remy du Puys, archivist and historiographer to both Maximilian and Charles, by order of his sovereign and in return for a payment of 150 pounds (pounds of 40 groats) from the Receiver General. ${ }^{54}$ The city of Bruges paid him an additional 5 pounds groten 'for the trouble and effort of recording in Walloon the Triumph of the Entry of our prince into this city' ('voor de moeite en arbeid om de Triomf van de Inkomst van onze prins in deze stad in het Waals te stellen'). ${ }^{55}$ The manuscript contains 62 pages and 32 full-page, coloured illuminations. The format is slightly smaller than the description of the entry into Brussels in 1496. It contans only half as many pictures, but a much more comprehensive literary description of the scenes and the event. This manuscript was very probably the one presented to Prince Charles himself. In Parıs, Gilles de Gourmont, using this text, produced a practically identical 40-page edition with 33 woodcuts, 27 of them full-page. ${ }^{56}$

On 25 June 1515, at Adriaan van Bergen's in Antwerp, a rhyming account of the triumph appeared in Dutch, which differed from Du Puys's text in only a few details. It ran to 18 pages and was not illustrated. The introduction makes no mention of an author but refers to the chamber of rhetoric. ${ }^{57}$ The city accounts of Bruges show payment of 2 pounds groten

\footnotetext{
${ }^{54}$ Vienna, Osterreichsche Nationalbibliothek, Codex 2591, $220 \times 305,32$ full-page paintıngs, 3 smalleı ones Facsimıle $S$ Anglo (ed), La tryumphante Entrée de Charles prince des Espagnes en Bruges 1515 (Amsterdam/New Yolk $\mathrm{nd}$ ), L P Gachatd, Collection des voyages des souverains des Pays-Bas, vol II (Brussels 1882) 531

${ }^{59}$ Bruges, Stadsarchief, Stadsıekening 1514-1515, 1 127r, Gachard, Voyages, 542

${ }^{56}$ La Tryumphante et solemnelle entree facte sur le nouvel et toyeux advenement de tres hault tres putssant et tres excellent prince monsteur Charles prince des Hespalgnes archiduc d'Austrice etc Several copies have been preserved, for example Leiden, Unıversitertsbibliotheek, Thysiana 916, Biussels, Koninklıke Bibliotheek, B 1553, 33 woodcuts, 6 half-page, 27 full-page, $255 \times 190 \mathrm{~mm}$

${ }^{57}$ De Triomphe gedaen te Brugghe binnen ter intreye van Caerle etc, The Hague,

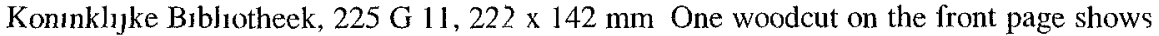
the arms of Bruges between two crowned letters ' $b$ '
} 
to Jan van Scheerere who had recorded the entry in verse ("die in dichte de Incomste gestelt heeft'), and of 2 shillings to Colaert d'Ault and Jooris Roelants for translating it into Walloon from the Flemish Jan van Scheerere was known to be a prominent rhetorician in Bruges, who was a member of the organizing committee paid by the town for planning and organizing the eleven tableaux vivants for the entry ${ }^{58} \mathrm{He}$ was, in all probability, the author of the printed Dutch-language account It is interesting that the city gave 5 pounds to the royal historian for his trouble (for which the court had already rewarded him richly), as opposed to 2 pounds to their fellow citizen and a mere 2 shillings for the translation By using printers in Paris and Antwerp the city council was probably anxious to ensure as much publicity as possible for the Bruges 'Trumph'

Thus in 1515 it was intended that hundreds of readers at home and dbroad should learn of the spectacle in Bruges, as well as the court itself, which made use of its own official to produce a luxury manuscript Not only the organization of the procession but also the international mass communication about it in word and picture had become the task of the receiving city council The text was full of praise for the Bruges triumph, presenting it as incomparable and most elegant, and showing quite clearly the spirit of competition behind such propaganda Chroniclers had already recorded that the entry of Philip the Good into Ghent was the most magnificent ever held ${ }^{59^{\circ}}$

A committee consisting of six rhetoricians and some members of the city council met frequently to put into effect the concept and elaboration of the spectacle The construction of eleven tableaux vivants was the respons1bility of this committee, two were in the hands of the Brugse Vrije, and fifteen were entrusted to the nations of foreign merchants These produced little symbolism, what there was being mostly heraldıc In the squares where they resided they constructed triumphal arches, galleries and towers in which the glories of therr country of origin - the German Empire, Spain, Italy - were linked in a glonfication of the young prince's dynasty ${ }^{60}$

\footnotetext{
${ }^{58}$ Bruges, Stadsarchief, City Account 1514 15, f 123v-124r In 1543 an epitaph enumer ated his functions as secretary to the imperial mint, pensionary of Bruges officer of the brokers' guld, member of the two rhetoricians' chambers and of the two archers' guilds Eduard de Dene, Testament rhetoricael eds W Waterschoot \& D Corgneau (Ghent 1979) $7-10$

${ }^{59}$ Dhanens, 'Blijde Inkomst', 58

${ }^{60} \mathrm{~J}$ Jacquot, 'Panorama des fêtes et ceremonies du regne', in J Jacquot (ed), Les Fêtes de la Renalssance II, Fêtes et ceremontes au temps de Charles Quint (Parı 1960) 418
} 
The tableaux presented by the city and the Brugse Vrije, on the other hand, consisted in every case of a scene from the history of Bruges and its surroundings, and a fitting biblical, classical or mythical parable. The overall theme was the growth, flowering and threatening decline of Bruges, set in an iron, silver and golden age. The first three scenes showed the early beginnings of the town. The central figures here were Liederic de Buc and the counts Baldwin with the Iron Arm and Thierry of Alsace. The next four scenes presented the counts of Flanders from the fourteenth and fifteenth centuries who assisted the further growth of the city: Louis of Nevers, Louis of Male, and the dukes of Burgundy, Philip the Bold and John the Fearless. Only then did the Golden Age begin, with dukes Philip the Good and Charles the Bold. After them, the Silver Age brought decline for Bruges; it was followed by the Iron Age. The latter two periods did not show princely figures but everyone knew very well that Emperor Maximilian, Charles's grandfather, was meant. However, the young Prince Charles now sat on the Wheel of Fortune and it lay in his power to raise up the people of Bruges - here presented as the children of Israel - into the forefront of races. The prophet Nehemiah asks King Ahasuerus to be allowed to rebuild Jerusalem when it had been destroyed. This scene concluded the procession in front of the Prinsenhof (the residence of the prince). It was staged by the brokers who were the ninth member of the corporate organization of Bruges. Each of the Nine Members, into which the 54 craft guilds were divided, was responsible for one tableau, as they had been in earlier processions in 1468 and $1497 .{ }^{61}$ In some cases the themes of the tableaux showed a connection with the professional activities practised by the organizing member. The butchers and fishmongers, for example, exhibited two mountains, on one of which were all sorts of cattle, with a golden ram on the top (an allusion to the Golden Fleece), and sea creatures on the other. The smiths displayed an enormous monstrance. The other tableaux generally kept to the symbolism of trade and industry. At the beginning of the procession by the Cruuspoorte gate, the poorterij, the organization of well-to-do citizens, had provided three tableaux about the rise of the town.

In that time of economic decline, the city government of Bruges used the occasion of Charles's entry as an enormous piece of propaganda. The message was a blatantly clear call to the young prince to help the town

${ }^{61} \mathrm{G}$. Degroote, Blijde Inkomst. Vier Vlaams-Bourgondische gedichten (Antwerp/ Amsterdam 1950) xxix. 
recover its lost prosperity. With the co-operation of civic bodies - the poorterij, the Nine Members of craft guilds, the foreign trading nations, the chambers of rhetoric and the archery associations - it produced a richly performed spectacle in the most modern Renaissance style. The prince's enthusiasm was evident when he had it repeated some days later. We know of no other city which delivered its message so conspicuously, with a great spectacle and printed accounts publicizing it in two languages and 33 illustrations. The message was clear but certainly not unusual. The exceptional media ensured its wide and lasting dissemination.

The town was a microcosm where all ranks and classes of late medieval society came into close and frequent contact. Stating one's position by showing distinction was more relevant there than elsewhere. The complexity of the urban community had found its corporate organization; in the manifestations described above it always formed the basis for the arrangement of the events. In a logical way every segment appeared in its proper place. For the city government these were opportunities to reaffirm the internal social order through experiencing it in a festive way. With the princely entries court and town entered into a dialogue by exhibiting the internal hierarchy through their emblems. The towns made increasing use of such occasions to send out their own messages, which were made clear through their consistent structure. The message included something for the occasion as well as providing information about the position of the town in relation to another. The element of rivalry in the artistic means employed proved ideal for this. Rivalries, which had been fought between bishops, princes and noblemen for centuries, occurred in a similar way between the urban corporations and between the towns themselves. ${ }^{62}$

All this symbolic show did not stand apart from the 'real' political process; it was an integral part of it. The ritual manifestation of new or established relations made it possible to build further contacts. The expression of mutual love, or even patriae potestas, in an atmosphere of collective emotions, formed an essential method of cementing relations between ruler and subjects and between different sectors of the urban community. By thus showing itself to the ruler, it strengthened its internal cohesion in spite of all the tensions of daily intercourse. The ritual deliberately sublimated the real differences only to enclose them in clearly

${ }^{62}$ Compare with Spieß, 'Rangdenken und Rangstreit'. 
defined categories in a wider symbolic union. The dramatization of this added a deeply felt dimension to the political process that could never more get around this privileged moment. ${ }^{63}$

\footnotetext{
${ }^{6.3}$ Compare the conclusions of Arnade, Realms of Ritual, 211-13.
} 